\title{
Efektivitas Ekstrak Daun Srikaya (Annona Squamosa L) Sebagai Insektisida Nabati Terhadap Hama Ulat Grayak (Spodoptera Litura)
}

\author{
Zelita Fitri Ente ${ }^{1 *}$, Opir Rumape ${ }^{1}$, Suleman Duengo ${ }^{1}$ \\ ${ }^{1}$ Program Studi Kimia, Universitas Negeri Gorontalo, Jl. Prof. Ing. B.J Habibie, Kampus Baru Bone Bolango
}

\begin{abstract}
ABSTRAK
Penelitian ini bertujuan untuk mengetahui kandungan senyawa metabolit sekunder pada ekstrak daun srikaya (Annona squamosa L) sebagai insektisida nabati yang dapat menyebabkan mortalitas terhadap hama ulat grayak (Spodoptera litura). Metode yang digunakan adalah ekstraksi maserasi dengan pelarut metanol dan difraksinasi dengan pelarut $n$-heksan dan etil asetat. Uji fitokimia dari ekstrak kental metanol daun srikaya memberikan hasil positif untuk empat senyawa metabolit sekunder antara lain flavonoid, alkaloid, terpenoid dan saponin, sedangkan untuk steroid memberikan hasil negatif. Uji mortalitas terhadap fraksi dari ekstrak daun srikaya antara lain fraksi metanol, etil asetat dan n-heksan dilakukan pengamatan selama $1 \times 24$ jam, ditemukan fraksi metanol pada variasi konsentrasi $1 \%, 2,5 \%, 5 \%, 7,5 \%$, dan $10 \%$ menunjukkan tingkat mortalitas hama sebesar $67 \%, 78 \%, 78 \%, 78 \%$ dan $100 \%$. Pada konsentrasi $10 \%$ memberikan pengaruh mortalitas paling tinggi sebesar $100 \%$. Fraksi etil asetat pada variasi konsentrasi $1 \%, 2,5 \%, 5 \%, 7,5 \%$, dan $10 \%$ menunjukkan tingkat mortalitas hama sebesar $44 \%$, $56 \%, 67 \%, 67 \%$ dan 78 . Pada konsentrasi $10 \%$ memberikan pengaruh mortalitas tertinggi sebesar $78 \%$. Fraksi $n$-heksan pada variasi konsentrasi $1 \%, 2,5 \%, 5 \%, 7,5 \%$, dan $10 \%$ menunjukkan tingkat mortalitas hama sebesar $22 \%, 44 \%, 56 \%, 67 \%$ dan $78 \%$. Pada konsentrasi $10 \%$ memberikan pengaruh mortalitas tertinggi sebesar $78 \%$.
\end{abstract}

Kata kunci: Daun srikaya; Insektisida Nabati; Uji Fitokimia; Uji Mortalitas

\begin{abstract}
This study aims to determine the content of secondary metabolites in the extract of srikaya leaf (Annona squamosa L) as a vegetable insecticide that can cause mortality in armyworm (Spodoptera litura) pests. The method used is maceration extraction with methanol solvent and fractionated with $n$-hexane and ethyl acetate solvent. Phytochemical test from methanol extract of srikaya leaves gave positive results for four secondary metabolites, including flavonoids, alkaloids, terpenoids and saponins, while steroids gave negative results. Mortality test on the fraction of srikaya leaf extract including methanol, ethyl acetate and $n$-hexane fractions was observed for $1 \times 24$ hours, methanol fraction was found at various concentrations of $1 \%, 2.5 \%, 5 \%, 7.5 \%$, and $10 \%$ showed pest mortality rates of $67 \%, 78 \%, 78 \%, 78 \%$ and $100 \%$. At a concentration of $10 \%$ gives the highest mortality effect of $100 \%$. Ethyl acetate fraction at variations in concentration of $1 \%, 2.5 \%, 5 \%, 7.5 \%$, and $10 \%$ showed pest mortality rates of $44 \%, 56 \%, 67 \%, 67 \%$ and 78. At a concentration of $10 \%$ had an influence the highest mortality was $78 \%$. The $n$-hexane fraction at various concentrations of $1 \%, 2.5 \%, 5 \%, 7.5 \%$, and $10 \%$ showed pest mortality rates of $22 \%, 44 \%, 56 \%$, $67 \%$ and $78 \%$. At a concentration of $10 \%$ the highest mortality effect was $78 \%$.
\end{abstract}

Keywords: Srikaya leaves; Vegetable Insecticide; Phytochemical Test; Mortality Test

\section{Received: 23-07-2019, Accepted: 23-02-2020, Online: 08-07-2020}

\section{PENDAHULUAN}

Spodoptera litura atau ulat grayak merupakan salah satu hama yang penting bagi petani, karena hama ini dapat menimbulkan kerusakan serius pada tanaman yang diserangnya (Permana, 2016). Serangan dari ulat grayak mampu memakan habis seluruh daun dan hanya menyisakan tulang-tulang daun, sedangkan pada serangan berat ulat grayak mampu

\section{*Corresponding author:}

zelita.ente@gmail.com 
menurunkan produktivitas tanaman bahkan hingga kegagalan panen (Agazali, 2015). Oleh karena itu, perlu upaya untuk menanggulangi hama tersebut. Pengendalian terhadap ulat grayak pada tingkat petani pada umumnya masih menggunakan insektisida yang berasal dari senyawa kimia sintetik yang dapat merusak organisme non target, resistensi hama, resurgensi hama dan menimbulkan efek residu pada tanaman dan lingkungan. Untuk meminimalkan penggunaan insektisida sintetik perlu dicari pengendalian pengganti yang efektif dan aman terhadap lingkungan (Safirah, 2016). Diperlukan alternatif insektisida yang ramah lingkungan dengan cara memanfaatkan senyawa racun yang terdapat pada tumbuhan yang dikenal dengan insektisida nabati (Permana, 2016). Insektisida nabati kembali mendapat perhatian menggantikan insektisida kimia sintetik karena relatif aman, murah, mudah aplikasinya di tingkat petani, selektif, tidak mencemari lingkungan, residunya relatif pendek, sehingga tidak menimbulkan pengaruh samping (Kadja, 2010).

Sifat dari insektisida nabati umumnya tidak berbahaya bagi manusia ataupun lingkungan serta mudah terurai dibandingkan dengan insektisida sintetik. Insektisida nabati ini bisa berfungsi sebagai penolak, penarik, pembunuh, antifertilitas dan bentuk lainnya (Wiridianti, 2015). Pemanfaatan insektisida nabati selain dapat mengurangi dampak pencemaran lingkungan, bahannya mudah didapat dan harganya relatif lebih murah (Mawuntu, 2016). Tumbuhan memproduksi bahan kimia alami sebagai alat pertahanan diri terhadap serangga pengganggu.

Tumbuhan mengandung bahan kimia dalam bentuk senyawa metabolit sekunder yang fungsinya dalam proses metabolisme tumbuhan masih kurang jelas. Namun, kelompok senyawa ini ternyata berperan penting dalam proses berinteraksi atau berkompetisi, termasuk melindungi diri dari gangguan pesaingnya. Produk metabolit sekunder tersebut dapat dimanfaatkan sebagai bahan aktif pestisida nabati dan juga digunakan oleh tumbuhan sebagai alat pertahanan dari serangan organisme pengganggu (Saenong, 2016). Telah banyak bukti memperlihatkan bahwa tumbuhan merupakan gudang bahan kimia yang disebut produksi metabolit sekunder. Bahan kimia ini digunakan untuk melindungi diri dari berbagai gangguan organisme pengganggu tumbuhan (Sonyaratri, 2006). Berbagai ekstrak tumbuhan yang dapat dijadikan pestisida nabati untuk mengendalikan ulat daun diantaranya ekstrak biji mahkota dewa dan biji mimba, daun srikaya, daun pepaya, daun mindi dan lain-lain (Deden, 2017).

Salah satu jenis tumbuhan yang berperan sebagai insektisida nabati adalah srikaya (Annona squamosa L). Bagian-bagian tumbuhan srikaya berkhasiat untuk obat-obatan, bahkan bisa bersifat pembunuh serangga (Windasari 2011). Srikaya mengandung senyawa bioaktif yang bekerja sebagai insektisida. Senyawa annonain yang terkandung dalam srikaya dapat berperan sebagai insektisida, larvasida, repellent dan antifeedant dengan cara kerja sebagai racun kontak dan racun perut (Wiryadiputra, 1998). Menurut Purwita (2013), Kandungan senyawa metabolit sekunder pada srikaya ialah glikosida, alkaloid, saponin, flavonoid, tanin, karbohidrat, protein, senyawa fenolik, pitosterol, dan asam amino. Penelitian yang dilakukan oleh Melliawati (2017) menunjukkan bahwa daun srikaya mengandung alkaloid, glikosida sianogen, flavonoid, fenol, saponin, dan terpenoid.

Selama ini penggunaan pestisida nabati khususnya pemanfaatan srikaya masih sangat jarang, berbagai penelitian yang telah dilakukan memberikan tanggapan bahwa tumbuhan srikaya ini mengandung zat annonain yang berperan sebagai pestisida nabati terhadap serangga hama (Windasari, 2011) sehingga pemberian ekstrak daun srikaya sangatlah penting dalam pemberantasan hama, khususnya hama ulat grayak yang mampu menurunkan produktivitas tanaman bahkan hingga gagal panen.

\section{METODE PENELITIAN Alat dan Bahan}

Alat-alat yang digunakan dalam penelitian ini diantaranya toples, , neraca analitik, blender, gelas ukur, gunting, tabung reaksi, rak tabung reaksi, cawan, batang pengaduk, gelas kimia, erlenmeyer, gunting, saringan, kapas, alumunium foil, satu set alat evaporator, satu set alat redestilasi, pipet mikro, botol-botol tempat sampel, corong pisah, pipet tetes, statif, klem, labu dasar bulat, spatula, oven. 
Bahan tumbuhan yang digunakan adalah bagian daun dari tumbuhan srikaya (Annona squamosa L) yang diperoleh dari Desa Dumbo Raya, Desa Bubeya Kecamatan Suwawa, Kabupaten Bone Bolango, Provinsi Gorontalo. Bahan kimia yang digunakan terdiri dari aquades, metanol, n-heksan, etil asetat, $\mathrm{H}_{2} \mathrm{SO}_{4}$ pekat, $\mathrm{NaOH}$, Kloroform, $\mathrm{HCl}$ pekat, serbuk Mg, dietil eter, dan pereaksi fitokimia (pereaksi Dragendorf, pereaksi Mayer, pereaksi Wagner, pereaksi Hager dan pereaksi Lieberman Bauchard).

\section{Tahapan Penelitian \\ Penyiapan Sampel}

Sampel yang digunakan dalam penelitian adalah daun srikaya sebanyak $\pm 2 \mathrm{~kg}$. Daun srikaya dicuci sampai bersih, digunting kecil kemudian diangin-anginkan selama 24 jam, setelah itu dihaluskan dengan cara diblender.

\section{Ekstraksi}

Sebanyak $\pm 2 \mathrm{~kg}$ sampel daun srikaya (Annona squamosa $L$ ) yang telah dihaluskan, dimaserasi dengan metanol selama $6 \times 24$ jam.Setiap 24 jam pelarut diganti dengan yang baru hingga filtrat tidak berwarna. Filtrat kemudian dipisahkan dan dikeringkan menggunakan evaporator pada suhu $40^{\circ} \mathrm{C}$ hingga diperoleh ekstrak kering atau kental.

\section{Fraksinasi}

Ekstrak kental metanol disuspensi dengan metanol dan air dan dipartisi dengan pelarut $\mathrm{n}$ heksan, diperoleh fraksi n-heksan dan fraksi metanol-air. Penambahan pelarut n-heksan ke dalam fraksi metanol-air dilakukan berulang kali sampai fraksi n-heksan menjadi bening selanjutnya dievaporasi, menghasilkan ekstrak n-heksan.Fraksi metanol-air dipartisi dengan pelarut etil asetat diperoleh fraksi metanol-air dan fraksi etil asetat. Penambahan pelarut etil asetat ke dalam fraksi metanol-air dilakukan berulang kali sampai fraksi etil asetat menjadi bening. Hasil partisi dari fraksi etil asetat dievaporasi pada suhu $30-45{ }^{\circ} \mathrm{C}$ sampai diperoleh ekstrak etil asetat.

\section{Uji Fitokimia}

Hasil maserasi dan hasil partisi diuji fitokimia untuk melihat kandungan senyawa metabolit sekunder yang terdapat di dalamnya.

\section{Uji Flavonoid}

Hasil maserasi dan ekstrak hasil partisi sebanyak $0,1 \mathrm{gr}$ dilarutkan dalam $10 \mathrm{~mL}$ metanol kemudian dibagi ke dalam empat tabung reaksi. Tabung pertama digunakan sebagai tabung kontrol, tabung kedua, ketiga, dan keempat berturut-turut ditambahkan $\mathrm{NaOH}, \mathrm{H}_{2} \mathrm{SO}_{4}$ pekat dan serbuk $\mathrm{Mg}-\mathrm{HCl}$ pekat. Warna pada masing-masing tabung dibandingkan dengan tabung kontrol, jika terjadi perubahan warna maka positif mengandung flavonoid.

\section{Uji Alkaloid}

Hasil maserasi dan ekstrak hasil partisi masing-masing sebayak 0,1 g diekstraksi dengan $10 \mathrm{~mL}$ kloroform amoniakal dan hasilnya dibagi menjadi dua bagian. Bagian pertama ditambahkan dengan sam sulfat $\left(\mathrm{H}_{2} \mathrm{SO}_{4}\right) 2 \mathrm{~N}$ dengan perbandingan volume yang sama, fraksi asam diambil dan dibagi menjadi tiga bagian. Kemudian dilakukan pengujian dengan menggunakan pereaksi Mayer, Dragendroff, dan wagner. Bagian kedua dilakukan pengujian dengan pereaksi Hager. Jika terbentuk endapan menunjukan adanya alkaloid.

\section{Uji Steroid, Terpenoid dan Saponin}

Hasil maserasi dan ekstrak hasil partisi masing-masing sebanyak $0,1 \mathrm{~g}$ dilarutkan dengan menggunakan $10 \mathrm{~mL}$ dietil eter. Ekstrak ekstrak yang larut dalam dietil eter di uji dengan menggunakan pereaksi Liebarman Bauchard (asam asetat anhidria : asam sulfat pekat). Jika terbentuk warna hijau kebiruan, menunjukan adanya steroid, sedangkan warna merah kecokelatan menunjukan adanya terpenoid. Sisa yang tidak larut dalam dietil eter, diuji 
dengan cara menambahkan $2 \mathrm{~mL}$ aquades panas. Jika terbentuk busa/buih yang cukup stabil (15 menit) setelah ditambahkan aquades panas, menunjukan adanya saponin.

\section{Uji Mortalitas}

Uji ini bertujuan untuk mengetahui aktivitas ekstrak daun srikayaterhadap mortalitas dan tingkat serangan hama ulat grayak (Spodoptera litura). Uji efek mortalitas dilakukan pada hama ulat grayak dengan menggunakan media uji daun padi, menggunakan larutan uji dari ekstrak kental metanol daun srikaya dan fraksi-fraksinya (n-heksan, etil asetat dan air) dengan konsentrasi $0 \%$ sebagai kontrol, $1 \%, 2,5 \%, 5 \%, 7,5 \%$ dan $10 \%$.Pengujian dilakukan berdasarkan konsentrasi yang akan digunakan.

Hama ulat grayak sebanyak 3 ekor masing-masing dimasukkan ke dalam toples-toples yang telah diberi alas berupa kain kasa basah. Tiap perlakuan diulangi sebanyak 3 kali ulangan sehingga jumlah unit percobaan sebanyak 18 kali percobaan. Setiap unit percobaan (tiap toples) diisi 3 ekor hama ulat grayak. Pakan berupa daun padi masing- masing diolesi dengan ekstrak daun srikaya berdasarkan tingkat perlakuan/konsentrasi yaitu $0 \%$ sebagai kontrol, $1 \%$, $2,5 \%, 5 \%, \quad 7,5 \%$ dan $10 \%$. Lalu ditutup dengan penutup yang telah dilubangi atasnya.Pengamatan ini dilakukan dengan menghitung jumlah larva yang mati dalam waktu 24 jam setelah pemberian beberapa konsentrasi ekstrak daun srikaya. Mortalitas larva dihitung menggunakan persamaan 1 (Permana, 2016).

$$
P 0=\frac{r}{n} \mathrm{X} 100 \%
$$

Keterangan:

$$
\begin{aligned}
& P_{o}: \text { Mortalitas larva } \\
& r: \text { Jumlah larva yang mati } \\
& \mathrm{n}: \text { Jumlah larva seluruhnya }
\end{aligned}
$$

\section{HASIL DAN PEMBAHASAN}

Sampel yang digunakan dalam penelitian ini adalah daun srikaya yang diperoleh dari Desa Dumbo Raya, Desa Bubeya Kecamatan Suwawa, Kabupaten Bonebolango, Provinsi Gorontalo. Sampel daun srikaya sebanyak $\pm 2 \mathrm{~kg}$ dicuci bersih, tujuannya untuk menghilangkan kotoran yang menempel pada daun. Daun srikaya yang di gunting kecil-kecil kemudian di keringkan pada suhu ruangan selama \pm 1 minggu tanpa terkena sinar matahari. Proses pengeringan ini bertujuan untuk menghilangkan kadar air dalam sampel. Selanjutnya menghaluskan sampel dengan cara diblender untuk memperoleh serbuk daun srikaya. Tujuan menghaluskan sampel agar ketika dimaserasi, pelarut akan lebih mudah bercampur dan menarik senyawa-senyawa kimia bahan alam yang diperlukan.

Serbuk daun srikaya yang diperoleh, diekstraksi menggunakan metode maserasi dengan pelarut metanol. Digunakan pelarut metanol karena sifatnya yang polar sehingga dapat menembus dinding sel jaringan daun dan biji dan dapat mengekstrak semua komponen senyawa kimia dalam jaringan tumbuhan, baik bahan yang bersifat non polar, setengah polar dan senyawa polar.Waktu maserasi dilakukan selama $6 \times 24$ jam. Setiap 24 jam hasil maserasi disaring dan residunya dimaserasi kembali dengan metanol yang baru. Maserat-maserat tersebut kemudian dipekatkan menggunakan vacum rotary evaporator pada suhu $30-40^{\circ} \mathrm{C}$ sehingga diperoleh ekstrak kental metanol yang berwarna hijau kehitaman sebanyak $100 \mathrm{gr}$ dengan rendemen $16,7 \%$.

\section{Fraksinasi}

Sebanyak $50 \mathrm{gr}$ ekstrak kental metanol dimasukkan ke dalam campuran pelarut metanol dan air dengan perbandingan 2:1 di mana volume metanol sebanyak $100 \mathrm{~mL}$ dan volume air sebanyak $50 \mathrm{~mL}$. Kemudian dipartisi dengan $\mathrm{n}$-heksan yang bersifat non-polar dengan volume $100 \mathrm{~mL}$. Hasil partisi pada corong pisah menjadi dua lapisan, lapisan atas merupakan fraksi nheksan dan lapisan bawah adalah fraksi metanol-air. Proses partisi dari setiap pelarut yang digunakan dilakukan berulang-ulang dengan volume pelarut yang sama hingga pelarutnya tak 
berwarna lagi. Fraksi n-heksan yang diperoleh dievaporasi dengan suhu $30-40^{\circ} \mathrm{C}$ hingga diperoleh ekstrak kental n-heksan sebanyak 4,64 gr. Selanjutnya untuk fraksi metanol-air dipartisi kembali dengan etil asetat yang bersifat semi polar dengan volume $100 \mathrm{~mL}$. Hasil partisi pada corong pisah menjadi 2 lapisan yaitu lapisan atas fraksi etil asetat dan lapisan bawah fraksi metanol-air. Kedua fraksi tersebut masing-masing diuapkan. Fraksi etil asetat diuapkan dengan menggunakan rotary evaporator, hingga diperoleh ekstrak etil asetat sebanyak 3,34 gr.

Sisanya adalah ekstrak metanol yang cukup diuapkan dengan cara menaruh ekstrak didalam cawan penguap yang didiamkan selama beberapa hari, dan diperoleh $10 \mathrm{gr}$ ekstrak metanol.Pelarut yang digunakan pada tahap ini adalah berdasarkan tingkat kepolarannya yaitu metanol, n-heksan dan etil asetat. Metanol merupakan pelarut polar, sehingga senyawasenyawa yang bersifat polar akan tertarik. Untuk n-heksan merupakan pelarut non polar, sehingga senyawa-senyawa yang bersifat non polar akan tertarik. Untuk etil asetat merupakan pelarut semi polar, sehingga senyawa yang bersifat semi polar juga akan ikut tertarik.

\section{Uji Fitokimia}

Hasil maserasi dan evaporasi ekstrak daun srikaya diuji fitokimia untuk mengidentifikasi adanya senyawa metabolit sekunder dalam sampel. Uji fitokimia yang dilakukan antara lain uji flavonoid, alkaloid, steroid, terpenoid dan saponin. hasil uji fitokimia ekstrak metanol daun srikaya disajikan pada tabel 1.

Tabel 1. Hasil Uji Fitokimia Ekstrak Metanol Daun Srikaya

\begin{tabular}{cllcl}
\hline No & $\begin{array}{c}\text { Golongan I } \\
\text { Senyawa }\end{array}$ & \multicolumn{1}{c}{ Pereaksi } & Hasil Uji & \multicolumn{1}{c}{ Keterangan } \\
\hline 1 & Flavonoid & $\mathrm{NaOH}$ & + & Hijau pekat \\
& & $\mathrm{H}_{2} \mathrm{SO}_{4}$ & + & Cokelat \\
& & $\mathrm{Mg}-\mathrm{HCl}$ & + & Cokelat-hijau \\
2 & Alkaloid & Hager & + & Terdapat endapan hitam \\
& & Mayer & + & Terdapat endapan hitam \\
& & Wagner & + & Terdapat endapan hitam \\
& & Dragendroff & + & Terdapat endapan hitam \\
3 & Steroid & Lieberman-Bounchard & - & Tidak terbentuk warna hijau \\
4 & Terpenoid & Lieberman-Bounchard & + & Mebiruan \\
5 & Saponin & Aquades Panas & + & Terah kecokelatan \\
\hline
\end{tabular}

\section{Uji Mortalitas}

Pada uji ini dilakukan dengan menghitung jumlah hama yang mati dalam waktu 24 jam setelah pemberian beberapa konsentrasi ekstrak metanol daun srikaya. Terhadap ekstrak hasil fraksi (n-heksan, etil asetat dan metanol) dilakukan uji mortalitas dengan variasi konsentrasi $0 \%$ sebagai kontrol, $1 \%, 2,5 \%, 5 \%, 7,5 \%$ dan 10\%. Masing-masing larutan dioles merata pada tiap 3 potongan daun padi yang sudah dicuci dan dikeringkan. Kemudian dimasukkan kedalam masing-masing toples yang pentupnya telah dilubangi bagian atas. Dimasukkan juga 3 ekor ulat grayak yang telah dipuasakan selama 8 jam pada masing-masing toples yang berisi daun padi (yang diberi perlakuan). Adapun mortalitas hama ulat grayak setelah perlakuan berbagai tingkat konsentrasi ekstrak metanol daun srikaya selama 24 jam ditunjukan pada Tabel 2.

Berdasarkan hasil uji mortalitas dengan menggunakan berbagai macam fraksi antara lain fraksi metanol, etil asetat dan n-heksan, terlihat banyak hama yang mati pada fraksi metanol dengan konsentrasi $10 \%$. Adapun persentase tingkat mortalitas hama ulat grayak setelah perlakuan berbagai tingkat konsentrasi ekstrak metanol daun srikaya selama 24 jam ditunjukan pada Gambar 1. 
Tabel 2. Uji Mortalitas Hama Ulat Grayak setelah Perlakuan Berbagai Tingkat Konsentrasi Ekstrak Metanol Daun Srikaya Selama 24 jam

\begin{tabular}{|c|c|c|c|c|c|c|c|c|c|c|c|}
\hline \multirow{2}{*}{ Pelarut } & \multirow{2}{*}{$\begin{array}{l}\text { Konsentrasi } \\
\text { Larutan (\%) }\end{array}$} & \multicolumn{3}{|c|}{$\begin{array}{c}\text { Perlakuan } \\
1\end{array}$} & \multicolumn{3}{|c|}{$\begin{array}{c}\text { Perlakuan } \\
2 \\
\end{array}$} & \multicolumn{3}{|c|}{$\begin{array}{c}\text { Perlakuan } \\
3 \\
\end{array}$} & \multirow{2}{*}{$\begin{array}{c}\text { Rata-rata } \\
\text { Mortalitas } \\
(\%)\end{array}$} \\
\hline & & $r$ & $\mathbf{n}$ & $\%$ & $r$ & $\mathbf{n}$ & $\%$ & $r$ & $\mathbf{n}$ & $\%$ & \\
\hline \multirow{6}{*}{ Metanol } & 0 & 0 & 3 & 0 & 0 & 3 & 0 & 0 & 3 & 0 & 0 \\
\hline & 1 & 3 & 3 & 100 & 2 & 3 & 67 & 1 & 3 & 33 & 67 \\
\hline & 2.5 & 3 & 3 & 100 & 2 & 3 & 67 & 2 & 3 & 67 & 78 \\
\hline & 5 & 2 & 3 & 67 & 2 & 3 & 67 & 3 & 3 & 100 & 78 \\
\hline & 7.5 & 3 & 3 & 100 & 2 & 3 & 67 & 2 & 3 & 67 & 78 \\
\hline & 10 & 3 & 3 & 100 & 3 & 3 & 100 & 3 & 3 & 100 & 100 \\
\hline \multirow{8}{*}{ N-Heksan } & 0 & 0 & 3 & 0 & 0 & 3 & 0 & 0 & 3 & 0 & 0 \\
\hline & 1 & 1 & 3 & 33 & 0 & 3 & 0 & 1 & 3 & 33 & 22 \\
\hline & 2.5 & 1 & 3 & 33 & 1 & 3 & 33 & 2 & 3 & 67 & 44 \\
\hline & 5 & 1 & 3 & 33 & 2 & 3 & 67 & 2 & 3 & 67 & 56 \\
\hline & 7.5 & 2 & 3 & 67 & 1 & 3 & 33 & 3 & 3 & 100 & 67 \\
\hline & 10 & 2 & 3 & 67 & 2 & 3 & 67 & 3 & 3 & 100 & 78 \\
\hline & 0 & 0 & 3 & 0 & 0 & 3 & 0 & 0 & 3 & 0 & 0 \\
\hline & 1 & 3 & 3 & 100 & 0 & 3 & 0 & 1 & 3 & 33 & 44 \\
\hline \multirow{4}{*}{ Etil Asetat } & 2.5 & 2 & 3 & 67 & 1 & 3 & 33 & 2 & 3 & 67 & 56 \\
\hline & 5 & 2 & 3 & 67 & 2 & 3 & 67 & 2 & 3 & 67 & 67 \\
\hline & 7.5 & 1 & 3 & 33 & 2 & 3 & 67 & 3 & 3 & 100 & 67 \\
\hline & 10 & 2 & 3 & 67 & 2 & 3 & 67 & 3 & 3 & 100 & 78 \\
\hline
\end{tabular}

Keterangan: $\quad \%=$ Persentase mortalitas hama; $r=$ Jumlah hama yang mati $; n=$ Jumlah hama seluruhnya

Untuk fraksi n-heksan, peningkatan konsentrasi diikuti dengan peningkatan mortalitas hama, dimana persentase tertinggi terdapat pada konsentrasi $10 \%$.

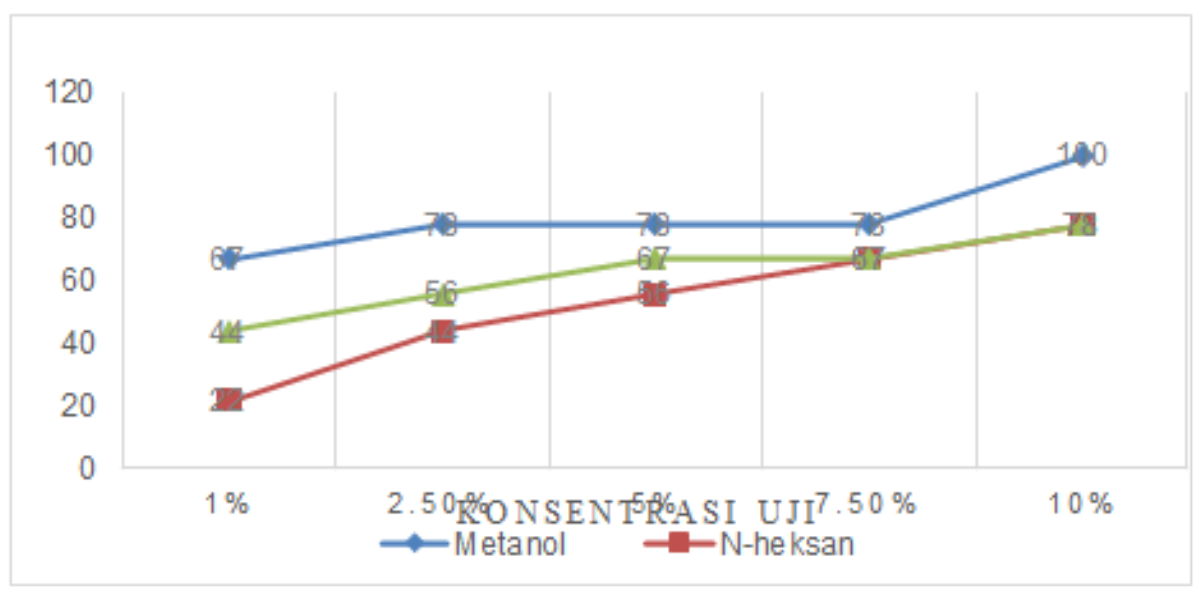

Gambar 1. Grafik mortalitas hama ulat grayak setelah perlakuan berbagai tingkat konsentrasi ekstrak metanol daun srikaya selama 24 jam

Sama halnya dengan fraksi etil asetat dengan persentase mortalitas tertinggi yaitu pada konsentrasi $10 \%$. Sehingga pada konsentrasi $1 \%$ dan $2 \%$ pada fraksi etil asetat dan $n$-heksan 
tidak berpengaruh nyata atau signifikan, sedangkan pengaruh nyata baru terlihat pada fraksi metanol.

Pada fraksi metanol dengan konsentrasi 2,5\%-7,5\% rata-rata mortalitas mencapai $78 \%$ sedangkan pada konsentrasi $10 \%$ rata-rata mortalitas mencapai $100 \%$.Sehingga pada konsentrasi $10 \%$ tersebut memiliki pengaruh paling tinggi terhadap mortalitas dan menjadi konsentrasi yang paling mempengaruhi pada pola mortalitas hama ulat grayak, karena dapat membunuh hingga 100\% hama. Hal ini menunjukkan bahwa ekstrak dari fraksi metanol bekerja dengan baik karena dapat membunuh hingga 100\% hama ulat grayak.

Menurut penelitian yang dilakukan oleh Permana (2016), suatu insektisida dikatakan efektif apabila mampu mematikan minimal $80 \%$ serangga uji.Diduga senyawa kimia yang terkandung dalam daun srikaya yang memberikan efek tersebut terhadap ulat grayak yaitu senyawa flavonoid, alkaloid, terpenoid dan saponin. Menurut Robinson (1995) dalam Hendrik (2016), tanaman yang mengandung komponen aktif seperti alkaloid, terpenoid, kumarin, glikosida dan beberapa sterol serta minyak atsiri dapat berpotensi sebagai insektisida. Beberapa tanaman yang mampu mengendalikan hama yaitu dari famili Anonaceae (srikaya, sirsak, buah nona) dan famili Meliaceae (mimba, aglaia) (Plantus, 2008). Sinaga (2009) menyatakan bahwa kandungan metabolit sekunder dalam tanaman seperti glikosida flavonoid bersifat racun perut yang bekerja apabila senyawa tersebut masuk dalam tubuh serangga, maka akan mengganggu organ pencernaannya.

Senyawa toksik yang masuk kedalam tubuh serangga akan mempengaruhi metabolisme dalam tubuhnya. Wardani (2010) dalam penelitiannya menunjukkan bahwa senyawa metabolit sekunder lain yang diduga menyebabkan mortalitas ulat grayak adalah saponin. Saponin merupakan racun perut bagi larva. Jika senyawa tersebut masuk dalam tubuh larva maka alat pencernaannya akan menjadi terganggu.Senyawa saponin dapat bersifat sebagai insektisida, yaitu dengan mengubah perilaku makan serangga dengan cara menghambat makanan pada saluran pencernaan.

Pada tabel 2 menunjukkan bahwa rata-rata persentase mortalitas pada ekstrak kental metanol memiliki persen mortalitas lebih tinggi dibandingkan ekstrak hasil fraksi n-heksan dan etil asetat. Hal ini dikarenakan ekstrak kental metanol diduga masih memiliki kandungan senyawa alkaloid dan flavonoid yang tinggi karena belum mengalami proses fraksinasi atau belum dipisahkan, dan kemungkinan besar senyawa yang terkandung dalam ekstrak metanol masih saling mendukung (Utina, 2015).

\section{SIMPULAN}

Berdasarkan hasil uji fitokimia ekstrak metanol daun srikaya mengandung senyawa flavonoid, alkaloid, terpenoid dan saponin. Hasil uji mortalitas hama ulat grayak terhadap fraksi metanol, etil asetat dan n-heksan memberikan hasil tertinggi pada konsentrasi $10 \%(100 \%)$, $10 \%(78 \%)$ dan 10\% (78\%). Berdasarkan hasil tersebut terlihat bahwa fraksi metanol memberikan efek mortalitas tertinggi. Penelitian dapat dikembangkan untuk mengidentifikasi dan mengisolasi senyawa tersebut dengan menggunakan metode analisis UV-Vis, FTIR dan NMR untuk memastikan struktur molekul dari isolat aktif.

\section{DAFTAR PUSTAKA}

Agazali et al. (2015). Efektivitas Insektisida Nabati Daun Tanjung dan Daun Pepaya Terhadap Mortalitas Ulat Grayak (Spodoptera Litura). Berkala IImiah PERTANIAN. Volume $x$, Nomor $x$, Bulan xxxx, hlm $x$

Akhsanita, Mardha. (2012). Uji Sitotoksik Ekstra, Fraksi dan Sub-Fraksi Daun Jati dengan Metoda Brine Shrimp Lethality Bioassay. Skripsi. Fakultas Farmasi Universitas Andalas: Padang 
Arifuddin, M. (2013). Sitotoksisitas bahan Aktif Lamun Dari Kepulauan Spermonde Kota Makassar Terhadap Artemia salina (Linnaeus , 1758). Skripsi. Fakultas IImu Kelautan dan Perikanan Universitas Hasanuddin: Makassar

Asmara, Anjar. (2017). Uji Fitokimia Senyawa Metabolit Sekunder Dalam Ekstrak Metanol Bunga Turi Merah (Sesbania grandiflora L. Pers). Al-Kimia Volume 5 Nomor 1

Deden. (2017). Efektivitas Pestisida Nabati Terhadap Pengendalian Ulat Grayak (Spodoptera sp.) Pada Tanaman Sawi (Brassica sinensis L.). JURNAL LOGIKA, Vol XIX No 1 April 2017

Harvey, David. (2000). Modern Analytical Chemistry. The Mc-Graw Hill Companies, Inc. DePauw University.

Hendrik. (2016). Pengaruh Jenis Pestisida Nabati Terhadap Serangan Hama Gudang Kutu Beras (Sitophylus oryzae L.) Pada Berbagai Jenis Beras. Skripsi. Sekolah Tinggi Ilmu Pertanian (STIPER) Dharma Wacana Metro: Kota Metro.

Huruse, Marniyati. (2015). Isolasi dan Karakterisasi Senyawa Metabolit Sekunder Dari Akar Tuba (Derris elliptica (Roxb) Benth). Skripsi. Jurusan pendidikan Kimia Universitas Negeri Gorontalo: Gorontalo

Kadja, Don. (2010). Annona Squamosa Sebagai Alternatif Aman Bagi Pengenalian Hama. Media Exacta Vol.10.

Mawuntu. (2016). Efektivitas Ekstrak daun Sirsak Dan Daun Pepaya Dalam pengendalian Plutella xylostella L. (Lepidoptera; Yponomeutidae) Pada Tanaman Kubis Dikota Tomohon. Jurnal IImiah Sains Vol. 16 No. 1

Melliawati, R., Sunifah. (2017). Mikroba Endofit Dari Tanaman Srikaya (Annona squamosa L.) sebagai Penghasil Antimikroba. Berita Biologi, Vol. 16 No. 1

Permana et al., (2016). Pemanfaatan ekstrak daun karuk (piper sarmentosum) sebagai insektisida nabati hama ulat grayak (Spodoptera litura). Ekologia : Jurnal IImiah IImu Dasar dan Lingkungan Hidup, Volume 18, Nomor 2

Purwita et al.,. (2013). Penggunaan Ekstrak Daun Srikaya (Annona squamosa) sebagai Pengendali Jamur Fusarium oxysporum secara In Vitro. LenteraBio Vol. 2 No. 2, Mei 2013:179-183

Saenong, M. S. (2016). Tumbuhan Indonesia Potensial sebagai Insektisida Nabati untuk Mengendalikan Hama Kumbang Bubuk Jagung (Sitophilus sp.). Jurnal Litbang Pertanian Vol. 35 No. 3

Safirah et al.,. (2016). Uji Efektivitas Insektisida Nabati Buah Crescentia cujete dan Bunga Syzygium aromaticum Terhadap Mortalitas Spodoptera litura Secara InVitro Sebagai Sumber Belajar Biologi. Jurnal Pendidikan Biologi Indonesia Volume 2 Nomor 3

Sonyaratri, Dessy. (2006). Kajian Daya Insektisida Daun (Azadirachta indica A. Juss) dan ekstrak daun Mindi (Melia azedarach L. ) Terhadap Perkembangan serangga Hama Gudang Sitophilus zeamais Motsch. Skripsi. Fakultas teknologi Pertanian IPB: Bogor. 
Utina, Nurfauzia. (2015). Uji Aktivitas Antifeedant Dari Ekstrak Metanol Biji Mahoni Terhadap Epilachna varivestis. Skripsi. Jurusan pendidikan Kimia Universitas Negeri Gorontalo: Gorontalo.

Wardani, Ratih. (2010). Pengaruh Konsentrasi Ekstrak Daun Tembelekan (Lantana camara) Terhadap Kematian Larva aedes aegypti. JURNAL KESEHATAN MASYARAKAT INDONESIA Vol 6, No 2

Indasari, N. (2011). Toksisitas Ekstrak Biji Srikaya (Squamosae semen) dan Pengaruhnya Terhadap Viabilitas Rayap Kayu Kering (Cryptotermes cyanocephalus). [Skripsi]. Universitas Negeri Semarang: Semarang

Isnaini, M., Pane, E., \& Wiridianti, S. (2015). PENGUJIAN BEBERAPA JENIS INSEKTISIDA NABATI TERHADAP KUTU BERAS (Sitophilus oryzae L). Jurnal Biota, 1(1), 1-8

Wiryadiputra, Soekadar. (1998). Percobaan Pendahuluan Pengaruh Minyak Mimba Dan Ekstrak Biji Srikaya Terhadap Mortalitas Helopeltis SP. Jurnal Perlindungan Tanaman Indonesia. Vol.4 No.2, 97-105 